The Orientalism of Arabs in Larry Charles Film's The Dictator

\author{
Iyank Zona Brammastian $^{1}$ \\ Karunia Purna Kusciati ${ }^{2}$ \\ Universitas Sebelas Maret
}

\begin{abstract}
Author Note
${ }^{1}$ Author is a student of English Department, Faculty of Cultural Sciences, Universitas Sebelas Maret, Jalan Ir. Sutami 36A, Surakarta, Indonesia

${ }^{2}$ Author is a lecturer of English Department, Faculty of Cultural Sciences, Universitas Sebelas Maret, Jalan Ir. Sutami 36A, Surakarta, Indonesia
\end{abstract}




\begin{abstract}
This article aims to portray the Orientalism of Arabs in Larry Charles's film The Dictator (2012). The research applies Edward Said's Orientalism to interpret the Western perspective in representing the awful images of the Arabs in the film. It also deploys post-colonial discourse and comedy film theory in defining the distorted images of Arabs which are often represented not as its natural form in this comedy genre film. As a result - throughout many Western and Orientalist creations - Arabs are depicted as bomber, barbaric and lustful.
\end{abstract}

Keywords: orientalism, Arabs, post-colonial, comedy genre. 


\section{The Orientalism of Arabs in Larry Charles Film's The Dictator}

Orientalism, a term which refers to the Western attitude in viewing the East, has already developed since the Enlightenment era. It can be seen from old works of literature or texts such as in Disraelli novel's Tancred that comes up with the ideas of East as a career. The other example is from the early painting which portrays the East as a lustful and exotic place, imbued with the romance of East and eroticism (Said, 1978, p. 6).

Orientalism can also be found in electronic media including film, not to mention Hollywood movies. It appears on various genres of film and also in more comedic and parodic movies. Orientalism in the Hollywood movies has become interesting discussion and debates among scholars. The debates and discussions on the issue also occur with the ugly portrayal attacking Arabs in the film.

Films such as The Sheik (1921), Harum Scarum (1965), True Lies (1994) and Three Kings (1999) portray the Orientalism issue of Arabs. The debates are about the imaginary images and the stereotype of Arabs. In fact, according to post-colonial views Orientalism is meant to show the Western power over the inferior Orient and as a form to deal with foreign or the Orient (Said, 1978, p.46).

The study from Rahman Ghauri and Mahmood focusing on Orientalism in electronic media elaborates that the art which depicts Arabs and Muslims cannot escape the development of deformation and modification. The Arabs and Muslims are presented in three ways: "Billionaire", "Bomber", and "Belly Dancer" (2016, p.10).

Najat Dajani (2000) gives many examples of orientalized Arabs and Muslims depicted in Hollywood movies. He argues that despite the improving images of Arabs through years, it does not appear that Hollywood immediately changes its view regarding what it obviously views as the enemy. Like in Mimi Leder film's The Peacemaker (1997), “America needs its enemies in 
order to emerge as the do-gooder" (Dajani, 2000, p. 75).

The Orientalism of Arab or Muslim can also be found in comedy genre movies. In comedy genre, the elements such as jokes and funny contents added to the movie could produce Orientalism issues which could be a serious matter for some audiences. Eventually, the comedy genre not only brings laughter by its joke, but also contains deep meaning in the joke itself which is well worth to discuss.

One of the comedy films which presents Orientalism issue of the Arabs is Larry Charles film's The Dictator (2012). The producer has said the character of Aladeen is inspired from the dictators such as Kim Jong-il, Idi Amin, Muammar Gaddafi, Mobutu Sese Seko and Saparmurat Niyazov. However, the main character of the movie is an Arab, who lives as a billionaire ruler that can have what he wants, a stereotype of Arab characterization on movies and TV series. The Dictator tells a story of Aladeen, the supreme leader of some Eastern countries called Wadiya. He executes everybody that disagrees with him, showing that he is a real dictator. American government and the world see Aladeen as a threat because he is developing a nuclear weapon. Everything goes smoothly until he needs to go to America and his right hand, uncle Tamir, betrays him as he loses his real identity and needs to act as an immigrant in America.

Glancing to the story of the film, this movie in some ways still presents some orientalism issues, although it is imbued with satire. Following the discussion on the Orientalism of Arabs, this study examines Larry Charles's The Dictator (2012) film in order to study the representation of Arabs in this comedy genre film. This research specifically examines the image of Arabs on Western perspective, whether this movie still continues to present the stereotype image of Arab or attempts to negotiate the stereotype, considering the context of contemporary American culture which is more egalitarian compared to the past.

\section{Methods}

This research is categorized into descriptive qualitative research. Thus, the analysis is in 
the form of interpretation of descriptive data. One typical characteristic of qualitative research is in its concern with meaning and interpretation in analyzing the research object (Stokes, 2003). The results of the interpretation are used to create a convincing argument and not only to find the definite meaning of the text.

The research takes Larry Charles's The Dictator (2012) movie as the main source of data. The data which are in the forms of narrative of the story and the scenes were analyzed by employing Charles S. Peirce's Semiotic. Thus, the data considered as signs which need interpretation in triadic mode to understand the signification of the movie to the context.

In relation with this concept, the sign is defined as an "object which is in relation to its object on the one hand and to an interpretant on the other... as to bring the interpretant into a relation to the object corresponding to its own relation to the object" (Ehrat, 2005, p. 117). Thus, the object is what the sign refers to, meanwhile the interpretant is the process in making sense the sign. Therefore, the sign which has relation with the object in the movie also has a relation to the reality, as the interpretant deals with the interpreter.

In this research, Edward Said's Orientalism is employed as an approach to analyze the representation of Arabs by the West to critically examine the Orientalism issues. Said defines Orientalism as "negative attitude of West in which they present East as uncivilized, sexual, lusty and revolutionary," (Mahmood \& Ghauri, 2016, p.12). Said (1978) argues that the distorted conception of East is to justify Western domination over East.

The theory is employed in this study as a stand point to study the facility of the West to know them, invade them and to conquer them (Said, 1978, pp. 91-92). It is to argue that such representation is produced with its main goal is to take advantage of Orient over its Western superiority. Orientalism is a man-made, it is "nothing more than a structure of lies or a myth," (Said, 1978, p. 21). Orientalism is a tool for Western to dominate East and a sign of EuropeanAtlantic power over the East. 


\section{Result}

1. The Representations of Arabs Country through Wadiya.

Wadiya is depicted as an Eastern country with some quality of Arab and Muslim which can be seen from the setting of the film. Led by Aladeen, Wadiya develops a nuclear weapon that become a serious concern to the Western world. Wadiya which presents some qualities of Arab and Muslim becomes a threat to the Western (Christianity) which reflects the early representation of Arab.

Early representations of Arabs and Muslims are drawn from literally works of nineteenth and twentieth centuries. Thus, they were influenced by depictions from the Elizabethan manuscripts that in fact such representation originated with the birth of Islam which was considered as a threat to the spread of Christianity (Dajani, 2000). These early representations of Arabs can also be seen in The Dictator film by a fantasy country called Wadiya.

Wadiya is a constructed setting portraying Middle Eastern region. In this case, it is a Western made-up setting in depicting the Arab territory in their own imagination, not as its true form, because in a film the setting often need to be constructed (Villarejo, 2013, p. 29). The constructed setting means to add the comedy element in the film. The comedy elements such as visualization jokes or what Lacey and Stafford (2002) called sight gag are presented in the setting of Aladeen's backyard showing Aladeen's face with his iconic beard craved on a pond. These depiction refers to the glamorous image of the rich Aladeen and labelled him as an Arab Muslim. The index which is the beard refers to Muslim man because it is one of the religious practices to grow beard.

Wadiya setting also provides some qualities of Arab country such as the desert and the Ottoman style building wose dome refers to a mosque. A mosque is the place for Muslim to do religious activities and worship, thus the film wants to show the connection of Middle Eastern region and its strong relation with Islam and Muslim. These two terms between Arab and 
Muslim are somehow interchangable, although they are actually different.

The movie depicts Wadiya as a threat to the world as it develops nuclear weapon. It represents the anxiety of the Western countries with the threat coming from Arab, as it has already happened with several cases such as terorrism acts conceded by some militant Arab groups to attack the West. The issue of Eastern threat also becomes a serious matter for the United Nations and also America. Americans also have their phobia of the threat coming from the Arabs as they suffer the terror that happened in World Trade Center. Thus, United States really concerns with this issue.

To strengthen the sign of Wadiya as a country which becomes Western enemy in the film, the national flag of Wadiya is constructed to resemble the Iraq national flag with its several similar attributes - the letter style and the green star shape. The movie still sends a message that the United States and Iraq have some issues starting from the Gulf War to other conflicts afterwards, where both countries suffer casualties.

In connection with the context of the history, although the conflict of both countries has been over, it still leaves a mark to most Americans, especially for the elderly who should join the war and the family of these soldiers. The tension between these two countries rose after the attack commited by The United States on February 25th, 1991 when a big Iraquian convoy was fleeing to Kuwait going on Highway 80. Around ten thousand people were killed including Kuwaiti hostages and some Iraqi civilians.

Another conflict afterwards continued with the revenge attack from Osama Bin Laden. He who curses US attack in Iraq was backed up with his organization known as Al Qaeda, causing rising tension between Islam and American. The tragedy exposes Islam as a threat as Osama urges the attack as 'the holy war' against the United States. Reflecting on the conflicts, the construction of Wadiya is depicted as Middle Eastern and Muslim country, a troublesome threat to United States. 
Based on the Wadiya depiction, the representation is still influenced by early works which portray Islam as a threat to the Western compartment. Regarding to the portrayal of Wadiya, it is a Hollywood movie product which is a Western-made product where the audience is watching the depiction of the Orient by Westerner perspective, by their imagination about Orient. Likewise with the Early representation of Orient in early theatrical drama where "the audience is watching a highly artificial enactment of what non-oriental has made into a symbol for the whole Orient," (Said, 1978, p. 71). Wadiya is constructed as the Orient, the alien, the opposite of the Western Occident.

\section{Aladeen The Bad Arab}

The name Aladeen is also a well-known name in Western film industries as it is similar with the Disney's Aladdin. In the Disney version, Aladdin is depicted as an Arab but with some of Western qualities such as his American accents and his clean-cut appearances. It is the opposite of the villain, Jafar, which is portrayed as the 'traditional' Arab with features such as its "Arabic accents, look different, and are sometimes villains," (Mott, 2015, p. 3). In the Dictator film, Aladeen character is more likely similar with the villain, Jafar, but his personality has gradually changed into more Western value as he starts loving Zoe the American girl.

Disney constructs Aladdin as an Arab but with some Western qualities, thus making his character relatable to the European audience and the character gets sympathy from its Western viewer (Mott, 2015, p. 1). Aladdin is the protagonist that can be considered as good character, but the characterization of Aladeen in The Dictator is the other way around and eventually can be considered as the bad one. Both depictions of the good Aladdin and the bad Aladeen are actually a constructed thought made by the film makers in order to make the audience believe that they are watching "Orientals not Orientalists” Mitchell (as cited in Mott, 2015). The audience is reinforced to believe that the image of the real Orient is similar with the 
depiction of Orient in the film. Thus, in this film the Orientalist wants to construct again the thought of its audiences by shifting Aladeen in less good version, away from Disney's version persona. Orientalism is a perspective to generalize the part of the world known as East. Thus, the depiction of Aladeen without any legitimate reason "brings millions of people in one simplified image to which it is wrongly assumed applies to all people of the Arab and East" (Mahmood \& Ghauri, 2016, p.9). Through the main character, Aladeen, Arab has the opposite quality of the Western value, which makes them the Orient. In The Dictator film, Aladeen is represented in three ways: bomber, barbaric and lustful.

First, Aladeen is represented as a bomber. The movie is in a comedy genre, thus many ugly depictions of Arab are delivered by jokes, gags or any comedy elements. In the film, Aladeen and his partner Nadal are suspected as hijackers while they take a tour by helicopter. They are trapped in situational comedy which is "all about social conflict" (Lacey \& Stafford, 2002, p. 6). The situation suddenly becomes awkward when Aladeen and Nadal speak in Arabic and the other two American passengers receive the meaning differently. They hear some familiar words such as 'Osama', '9/11' and 'Bin Laden', however, when speaking in Arabic, Aladeen and Nadal are actually talking about 'New Car series 911', and 'Osama Bin Laden pooping on his mansion', but the other two Westerners perceive the meaning differently. The scene is supposed to make us as the audiences laugh, as we know the situation better rather than the characters (Lacey \& Stafford, 2002, p. 6). That Osama bin Laden is a terrorist and 9/11 is a terror tragedy is unforgettable for Americans. These events create the image of bomber and terrorist embedded to Arab group. Through such representation, the movie seems to send a message that the prejudice towards Arab is so strong that anything could be interpreted to justify their prejudice.

Aladeen also wears a look-like-suicide-vest while he is in the helicopter. This scene produces the impression of the Americans Islamophobia of 9/11 of the hijacking tragedy. The 
retaliation of Osama due to the Gulf War becomes traumatic as it kills 2,996 civilians, according to History.com. The safety vest that Aladeen is wearing is interpreted the look-alike-suicide which makes them feel threatened and in danger. Therefore, the witty representation of Aladeen as a hijacker and bomber could produce the contrasted signification between the other characters in the movie and the audiences of the movie. It can be said that the movie also suggests that the sign could be misleading, depending on the interpreter. The scene also sends us message that it is not his true intention to do that, but he is stereotyped as such.

In this age of media and globalisation, Orientalists are found out "using wrong use of media and presenting ugly pictures of middle east," (Mahmood \& Ghauri, 2016, p. 5). Many jokes and pranks of Arabs bomber or terrorist spreading through the internet are considered as funny yet relevant. The Americans still tend to have Islamophobia since the $9 / 11$ tragedy, after Osama bin Laden, an Arab, claimed that he was the master plan of the terror. In the movie, Aladeen is considered as a threat for the Americans, due to the nuclear bomb that he develops.

United States suffers many bombing incident in dealing with Arabs. According to History.com, within the Iraq War in 2003-2011 many insurgent movements wanting to take control over the country after Saddam was defeated emerged. These insurgents bother the coalition army of US and NATO since they hide among the civilians. They threat and attack the coalition troops with suicide bombers and car bombs. When bombing each other is considered as common in war, the depiction of Arab as bomber is shown in many movies that trigger the stereotype. The Western fear of the real Arab terror is merely outside the war with the depiction of Aladeen nuclear threat which reflects American 9/11 trauma, the beginning of direct threat from Arab straight to the country. Thus, the generalization to view all Arabs as direct threat occurs and the stereotype of 'Arab bombers' is constructed.

Aladeen is depicted as an Arab bomber as he possess the bomb and gets label as terrorist as it might bring harm to others. Although America itself has nuclear weapon, they are not 
labeled terrorist. The comparison between these two is somehow imbalanced and once again Orientalism becomes a colonial discourse to make Orient powerless, as Edward Said mentioned that Orientalism is a "Western style for dominating, and having authority over the Orient" (as cited in Tepeciklioglu, 2012).

Second, Aladeen is represented as uncivilized or having barbaric character. The depiction of East is also not far from the term uncivilized, barbaric and the savageness of the Orient. In the film, Uncle Tamir replaces the real Aladeen with his dummy doppelganger who physically looks like the real one but he is mentally retarded. The distorted images of the barbaric Orient are depicted in the film through Aladeen doppelganger. The character can be categorized as a "character comedy" as he is the central character "with strong personalities who become the chief attraction in the story" (Lacey \& Stacey, 2002, p. 6). The barbaric attitude of Orient is shown when the Aladeen doppelganger is splashing his urine towards Israel delegation in a world conference. The scene shows his barbaric attitude when he is splashing his urine towards Israel delegation. It depicts the Middle East tension between Palestinian Arab and Israeli delivered with the 'gross-out' jokes when the doppel Aladeen break taboos by splashing his pee to the delegation.

Semiotically, the scene is the index of the conflict between Arabs and Israeli, since Israel formed a nation in Arab Palestinian region supported by United States de facto recognition and the United Nation's Partition Resolution which divide Palestine into two according to Halliday (1994). Arabs have disadvantage in dealing with the conflict with Israeli since their opposition is supported by Western power. Thus, the conflict in Palestine still happens nowadays.

The conflict between these two is handled by the UN, yet the result seems just one-sided. Israel has been committing war crime by expelling Palestinian from their land, driving terror to them, leading to the flight of almost 750.000 refugee camps in neighboring country and commit massacre to many Palestinian civilians (Henney, 2016). With the strong bilateral relationship 
between US and Israel, and the powerful position of US in the UN, the disadvantage is on the Arab Palestinian. The US can protect Israel from sanctions, in that situation "international law can become inconsistent and ineffective," (Henney, 2016, p. 24). Said (1978) also claimed that the International Relation concept deployed by the West often becomes troublesome, in this case the conflict between Arab Palestinian and Israeli since it is too far to meet its conclusion.

In the film, doppel Aladeen does inappropriate acts to Israel delegation. He splashes his urine to the delegation and pust it on a pitcher then disgustingly drink it. Thus, he is depicted as 'bad Arab' from doing that barbaric act, towards its opposition which is considered as the reversed version of the term bad, 'the good Israeli' for not being insulted by such things. The real Aladeen himself affirms his doppel action by saying "Oh that's a good one” on the next scene.

The Arabs are also pictured as a "brutal and murderous race that delighted in killing for fun" (Dajani, 2000, p.17). Just like the tittle of the film, Aladeen is the real dictator. He kills everybody that he dislikes, even just for a silly reason, he does not hesitate to execute the person. The dictatorship manner of Aladeen as a murderous Arab can be seen in the scene where Aladeen argues with Nadal about the shape of the rocket missile. After arguing with Nadal, Aladeen commands his troops to execute Nadal who does not agree with him.

The Arabs represented through Aladeen character above are represented in spoof or parody comic effect. The parody "is an exaggerated imitation" which "laughter depends on recognition of the object of the spoof or parody, which is mocked." (Lacey \& Stafford, 2002, p. 11). Aladeen is depicted as a murderous and barbaric being because he kills or executes people easily even for just a silly matter. The film is mocking the Arabs' hobby in war and killing, also their execution method. Chopping head as a method for the execution is considered as a sadistic way to end a life as it is an Arab method to execute a person and it is 'different' from Western style. Thus, Aladeen is represented as a cold hearted murderer, an Arab which enjoys his act in 
killing somebody.

Another savage behaviour represented by Aladeen is his cruel action due to the Menudo incident. He rapes several boys with their eyes open showing the cruelty of his barbaric manner. It also mentions the death of several boys after committing suicide because the savageness of Aladeen. In comedy films, there are several types of comic effects and one of which is black comedy. This scene can be included as a 'black comedy', while most of the comedy depends on challenging taboos, "but a black comedy goes much further and may include actions that don't seem to be part of the comedy genre at all” (Lacey \& Stafford, 2002, p. 11). Films with action and drama genre often include death as a part of their elements, but making joke of death is another matter and becomes parts of 'black comedy' element. These comic effects cover Aladeen barbaric actions toward the boys in Menudo incident in comical way, so that his 'taboo' act is delivered as a joke and a mockery of Arabs sexual deviancy.

Based on the previous scene Aladeen is also represented as lustful character. The portrayal of East in early films includes exotic and sensual as important elements. Ella Shohat in Dajani (2000) mentioned that East theme films come in common plot-lines such as "Rape and Rescue Fantasy", "the Imaginary of the Harem", and "the Desert Odyssey". In most cases, Islam and Muslims are associated with woman and sex as sort of their Muslim Paradise. Thus the women are represented as 'slaves' to their 'master', powerful women are considered as 'evil' and need to be disciplined (Dajani, 2000, p.17). Dajani also mentioned that women also give entertainment to their master by their knowledge of exotic dances. In The Dictator, this portrayal of the exotic East also occurs when Aladeen is surrounded by his female guardians which are also his harem.

In the harem scene, the women are depicted as 'slaves' as they are in form of commodity, a harem to please their master sexual desire. The following scene which portrays the women entertaining their master by kissing each other, added the sensual and exotic depictions of 
Eastern. The depiction of lesbianism in East is influenced by some early works such as Arabian Nights and an artist like Jean Auguste Dominique Ingres with his well-known painting Le Bain Turc (1862) or The Turkish Bath. This painting depicts a harem filled with nude women. It also shows the sexual intimacies between women as they are depicted kissing each other. Aladeen which is an Arab is considered as a lustful, a man with high sexual desires. Thus he has his own harem, as a part of his sensual and glamour life. The East is depicted as a dream world, a garden filled with maiden paradise (Dajani, 2000, p.22).

The representation of Aladeen as an Arab in this comedy film is somehow awful. He is depicted as the Orient with unknown and unfamiliar values for Westerners. Although the construction is in comedy ganre, it could still give serious effects to audiences. Comedy is often used by some producers as a weapon to react to the unknown and "at one time, anyone who was unlike 'us' was to be feared, and in these situations the basis for comedy could be racism or sexism (you may be surprised at how racist and sexist some films from the past can now seem). It is perhaps a sad reflection on the human condition, but most comedy is 'offensive' to someone (Lacey \& Stafford, 2012, p. 13). The Orientalism issue wrapped in comedy genre in this film somehow brings laughter to the audience, but the awful representation of Aladeen as an Arab is also offensive to some groups. The Dictator is a form of racial jokes about Arabs, but "if it wasn't the film, play, novel etc. would be bland and not very funny" (Lacey \& Stafford, 2012, p. $13)$.

The representation of East barbaric manner is considered as an Orientalism which Edward Said mentions as a form of thought to deal with East, to justify their invasion to the Orient because they are in need of salvation. The Dictator clearly depicts the Western power over the Orient that affirms Dajani's (2000) study which mentions the portrayal of Arabs as savage beings and the ones who need guidance from the Western power. It can be seen when Aladeen falls in love with an American woman named Zoey which helps him after his uncle's 
betrayal. Zoey is the one who changes Aladeen's mind in changing Wadiya to democratic country, instead of maintaining his dictatorship. Thus, it clearly implies that the Orient needs the Western involvement to help themselves. This type of plot-lines is influenced by the imperialistic perspective. The motives of the fabricated images addressed to Orient is clear, it "was a preface and reinforcement of the Western imperial rule over the Orient (Hamadi, 2014, p. 41).

\section{Conclusion}

The Hollywood movie which is directed by Larry Charles, The Dictator, clearly depicts the Orientalism of Arabs in several aspects. The representation of Arab countries is represented through a made-up or fantasy country, Wadiya, and the representation of Arabs is represented by the main character Aladeen which is portrayed as a 'bad Arab' through the film. First, Aladeen is depicted as an Arab bomber as he develops the nuclear bomb and labeled as terrorist as it might bring harm to others. Second, Aladeen is depicted as barbaric, a character with inappropriate manner and far from Western value. Third, Aladeen is depicted as lustful character which supports the depiction of exotic and erotic East. This movie continues to produce the construction of Arabs in Western myth, as savage and in need of salvation as Aladeen starts to shift his perspective because of Zoey, American woman,. Arabs distorted images such as bomber, barbaric and lustful which are depicted in the film are produced through many scenes. Thus, this study argues that this film is still to continue the established myth of the ideas and belief of Orientalism. In The Dictator film, Arabs are depicted in more negative way. The fabricated images of Arabs as the Orient is clear, to justify the Western imperial and ruling over Orient. 


\section{References}

Dajani, N. (2000). Arabs in Hollywood orientalism in film. The University of British Columbia, 2(1), 8-

13. Retrieved from http://rfh.org.pk/jur/magazinecategory/jpr

Ehrat, J. (2005). Cinema and semiotic - Peirce and film aesthetics, narration, and representation.

Canada: University of Toronto Press Incorporated.

Ghauri, R., \& Qaisar M. (2016). Orientalism in electronic media: A challenge for muslim world.

Punjabi: Journal of policy Research.

Halliday, F, (1994). The Gulf War 1990-1991 and the study of international relations. Review of international studies, 20(2). pp. 109-130. DOI: 10.1017/S026021050011784X

Hamadi, L. (2014). Edward Said: The postcolonoal theory and the literature of decolonization. Lebanese International University, retrieved from http://eujournal.org/index.php/esj/article/view/3689

Henney, C. (2016) Realism in the Israeli-Palestinian conflict: The influence of the United States of America and its allies and the inability of the United Nations in applying and executing the rules of International Law in the conflict. University of Free State, retrieved from https://www.researchgate.net/publication/327542673_Realism_in_the_IsraeliPalestinian_conflict_The_influence_of_the_United_States_of_America_and_its_allies_and_the_i nability of the United Nations in applying and executing the rules of International La

Lacey, N., \& Roy S. (2002). Comedy films for GSCE media. Media Education Magazine, 1-21.

Retrieved from http://www.itpmag.demon.co.uk/Downloads/GCS EC omedy.pdf

Mott, M. (2015). Aladdin's Orientalism and its Effects for Children, 1-8. Retrieved from http://melissamott.com/wp-content/uploads/2015/02/Aladdins-Orientalism.pdf

Said, E. (1978). Orientalism. London: Routledge.

Stokes, J. (2003). How to do media and cultural studies. London: Sage Publications

Tepeciklioglu, E. (2012). The Development of Postcolonial Theory. Bremen: Yasar University. 